\title{
3862, 3863, 3865 ve 3866 Numaralı Masraf Defterleri Işığında Şah Sultan'ın Yapmış Olduğu Harcamaların Sosyo-İktisadî Açıdan Analizi
}

\author{
Socio-Economic Analysis of Shah Sultan's Expenditures in the Light of Expense \\ Books Numbered 3862, 3863, 3865 and 3866
}

\author{
Arş. Gör. Dr. Erkan IŞIKTAŞ (iD)
}

\begin{abstract}
$\ddot{\mathbf{O} z}$
Osmanlı padişahlarının hanım sultanları, ikbâlleri veya kızlarına tahsis ettikleri meblağlar ve buna binaen onların yaptıkları harcamalar her devirde dikkat çekici olmuştur. İktisadî bağlamda kayda değer miktarlara ulaşan harcamaların içeriğini -ekseriyetle- yiyecek ve ısınma gibi muhtelif saray masrafları, sarayda görev yapan kişilere ödenen meblağlar, dokuma ürünleri, takı eşyaları, önemli kişilere sunulan ikramlar ve hediyelerle dini gün ve aylarda yapılan ihsanlar oluşturmaktadır. Osmanlı saray kadınlarının bu harcamalarını güç, gösteriş ve faziletin temsili olarak da değerlendirmek mümkündür. Ayrıca harcamaların yoğunlaştığı kalemler üzerinden saray kadınlarının yaşam tarzı, tüketim modelleri ve gündelik hayatlarına ilişskin birtakım çıkarımlara da ulaşmak söz konusu olabilmektedir. Bu itibarladır ki saray mensuplarının harcamalarını ihtiva eden tarihi arşiv dokümanlarının son derece önem arz ettiğini ifade etmek gerekir. Bu düşünceden hareketle ilgili çalışmada; hicri 1213-1217 (1798-1803) yılları arasını ihtiva eden masraf defterleri doğrultusunda Sultan III. Mustafa'nın kızı Şah Sultan'ın yapmış olduğu harcamaların sosyo-iktisadi bağlamda tarihsel bir analizi üzerine odaklanılmıștır. Araştırmada nitel araştırma yöntemlerinden biri olan tarihsel doküman analizi tekniği kullanılmıştır. Bu bağlamda Devlet Arşivleri Genel Müdürlüğü Osmanlı arşivlerinde yapılan incelemelerde Şah Sultan'ın giderlerini içeren toplam elli dört defter kaydına ulaşılmıştır. İncelenen defterler ışığında harcamaların cinsi, masraf bilançosunun yıllar bazındaki dağılımı ve emtia-fiyat ilişkisi irdelenmiştir. Ayrıca hanedan üyelerine ait hususi masraf defterlerinin önemine dikkat çekilmeye çalışılmıştır.
\end{abstract}

Anahtar Kelimeler: Osmanlı hanedanlığı, şah sultan, masraf defterleri, harcama kalemleri

Makale Türü: Araştırma

\begin{abstract}
The sums allocated by the Ottoman sultans to the lady Sultans and their daughters and their expenditures on this were remarkable in every era. The content of expenditures that reach significant amounts in an economic context consists of various palace expenditures, such as food and heating, sums paid to employees in the palace, weaving products, jewelry, and gifts offered to eminent people, and donations made on religious days and months. It is also possible to evaluate these expenditures of Ottoman palace women as a representation of power, panache and virtue. Furthermore, it may be possible to reach a number of inferences about the lifestyle, consumption models and daily lives of palace women through products which spending is concentrated. In this respect, it should be stated that the historical archive documents containing the expenses of the palace members are of great importance. In this study, the focus was on a historical analysis of the expenditures made by Shah Sultan in a socio-economic context in accordance with the expense books covering the years 1798-1803. Historical document analysis technique, one of the qualitative research methods, was used in the research. In total, fifty-four books containing the special expenses of Shah Sultan were reached during the examinations conducted in the Ottoman Archives of the General Directorate of State Archives. In this context, the type of expenditures,
\end{abstract}

\footnotetext{
${ }^{1}$ Siirt Üniversitesi, Fen Edebiyat Fakültesi, erkanisiktas@siirt.edu.tr.
} 
the distribution of the expense balance sheet on the basis of years and the relationship between commodity and price were examined during the period studied. In addition to this, it was attempted to draw attention to the importance of special expense books belonging to members of the dynasty.

Keywords: Ottoman dynasty, shah sultan, expense books, spending items

Paper Type: Research

\section{Giriș}

Osmanlı hanedanlı̆̆ı; siyasi ve askeri yönüyle birlikte saray yaşantısıyla da yerli ve yabancı araştırmacıların ilgi odağı olmuştur. Harem ile özdeşleşen bu yaşantı içerisinde; padişahların aile hayatı, kişilikleri, sosyo-kültürel aktiviteleri, hanedan üyeleri arasındaki çatışmalar ve saray kadınlarının iktidar ihtirasları gibi pek çok muhtelif mesele yer almış ve tarih araştırmalarına konu olmuştur (Ortayl1, 2008; Cenkmen, 1948; Bey ve Bobovius 2013; Akgündüz, 2000; Uluçay, 1992; Uluçay, 2001; Akyıldız, 2019). Bilhassa Osmanlı saray kadınlarının siyasi, iktisadi ve sosyal yönlerini ele alan çalışmalar son yıllarda artmış ve kıymetli çalışmalar ortaya konulmuştur (Kara, 2000).

Hâkeza Osmanlı arşiv merkezinde saray yaşantısıyla ilgili incelenmemiş çok sayıda belgenin bulunması ve konu itibarıyla popülerliğini devam ettirmesi sebebiyle bu tür çalışmaların daha da artacağı kanaati hâkimdir. Bu düşünceden hareketle hem mezkûr konuyu araştırmacıların ilgisine sunmak hem de alana katkı sağlamak maksadıyla Osmanlı saray kadınlarından birisi olan Sultan III. Mustafa'nın kızı Şah Sultan'ın masraf defterleri incelenmiştir.

Şah Sultan'ın biyografisine ilişkin kayıtların sınırlı olduğunu söylemek mümkündür. Bu nedenle literatürden edinilen kısıtlı bilgiler doğrultusunda Hanım Sultan'ın biyografisi kaleme alınabilmiştir. Şah Sultan, 20 Nisan 1761 senesinde doğmuştur. Annesi başkadın Mihrişah Sultan'dır. Diğer kız kardeşleri gibi kendisi de küçük yaşlarda vezir ve devlet adamlarıyla nikâhlandırılmıştır. Bu bağlamda Şah Sultan, 1764 senesinde veziriazam Bahir Köse Mustafa Paşa'ya nişanlandırılmıştır. Fakat veziriazamın önce görevinden azledilmesi ve akabinde idama mahkûm edilmesiyle nikâh düşmüştür. Şah Sultan, 1768'de Nişancı Mehmed Paşa ile -aynı yıl sadrazam olarak tayin edilmiş- nikâhlandırılmışsa da 1769 yılında mezkûr sadrazamın öldürülmesi suretiyle ikinci defa dul kalmıştır (Uluçay, 1992, s. 153-154).

1778 senesine gelindiğinde amcası I. Abdülhamid tarafindan Nişancı Seyit Mustafa Paşa'yla evlendirilmiştir. Bu evlilikten Şerife Havva isminde bir kızı olmuş (1780) ise de aynı yıl ölmüş ve Sultan III. Mustafa türbesine metfun olunmuştur. Hasta olması hasebiyle erken yaşta (42) vefat eden Şah Sultan (1803), Eyüp'te yaptırmış olduğu türbeye defnedilmiştir (Uluçay, 1992, s. 153-154). Şah Sultan'a babası, amcası ve kardeşi III. Selim birçok has ve mukataa tevcih ettiğinden iktisadi açıdan gelirleri oldukça iyi olduğu zikredilmektedir. Vakıf müessesesi kapsamında 1792'de Yeşildirek'te Kasım Gönanî Mescidi karşısında Şah Sultan çeşmesini 1800 'de Eyüp'te Zal Mahmud Paşa türbesi yanında Şah Sultan türbe, mektep ve sebilini yaptırmıştır (Parlak, 2010, s. 258-260).

Öte yandan literatür kaynaklarının yanı sıra Devlet Arşivleri Başkanlığı Osmanlı Arşiv merkezinde Şah Sultan ile ilgili muhtelif kayıtlar bulunmaktadır. Ancak bu kayıtların ekseriyeti, Hanım Sultan'ın çeşitli masraflarını ihtiva etmektedir. Bu belgeler doğrultusunda; Şah Sultan'ın sarayında müstahdem, arabacı, aşçı gibi iş görenlerin aylık ve yıllıkları ile yapılan masrafları (BOA, TS.MA.e, Gömlek No:152, Sıra No:2, s.1-3; BOA, TS.MA.e, Gömlek No:46, Sıra No:5, s.1-8), Şah Sultan çiftliğinin tamiri için yapılan masraf ve yevmiyeler, Sultan III. Mustafa'nın kızı Şah Sultan için yaptırdığı elbise ve oda takımlarının listesi (BOA, TS.MA.e, Gömlek No:151, Sıra No:35, s. 1-2), borçları (BOA, TS.MA.d, Gömlek No:2631, s. 1-3), saray ve çeşitli mukataalardan Şah Sultan'a tahsis edilen gelirlerin miktarları ortaya konulabilir (BOA, 
TS.MA.e, Gömlek No:151, Sira No:37, s. 1-6, BOA, TS.MA.e, Gömlek No:46, Sira No:8, s. 12). Bu kayıtların yanı sıra Şah Sultan'ın masraflarını gösteren yıl içerisinde ay bazında tutulan müstakil defterler de bulunmaktadır (BOA, TS.MA.d., Kutu Numaraları: 3862, 3863, 3865, 3866).

Çalışmanın esasını teşkil eden bu kaynaklar ışığında 1798-1803 yılları arasında Şah Sultan'ın masrafları üzerinden sosyo-iktisadi bağlamda tarihsel bir analiz yapmaya odaklanılmıştır. Bu kapsamda araştırmada; Hanım Sultan'ın yaşam tarzı, tüketim ürünleri ve gündelik hayatına ilişkin birtakım çıkarımlar ortaya konulmaya çalışılmıştır.

\section{Masraf Defterlerinin Muhtevası ve Tanıtımı}

Devlet Arşivleri Başkanlığı Osmanlı Arşivi’nde; Osmanlı Devleti'nin siyasi, iktisadi, sosyal ve idari konularıyla ilgili muhtelif masraf kayıtları muhafaza edilmektedir. Bu masraf kayıtları içerisinde yer alan ve Osmanlı hanedanlığının sosyo-iktisadi yaşantısı hakkında kıymetli malumatlar barından kayıt türlerinden birisini padişahların eşi veya kızlarının şahsi harcamalarının tutulduğu masraf defterleri oluşturmaktadır. Bu defterlerden elde edilecek bilgiler doğrultusunda hanedan üyelerine maaş niyetiyle tahsis edilen y1l/aylık meblağlar, ikamet ettikleri sarayların her türlü yiyecek ile 1sınma masrafları, kasr-1 hümâyûnların mefrûşât harcamaları ve sarayların tamirleri için yapılacak ödemelerin ortaya çıkartılması mümkün olabilmektedir. Haddizatında ağa, teberdaran ve hademelere ödenen miktarlar, çeşitli devlet adamlarına verilen hediyelerin bedelleri, dini ay ve günlerde yapılan ihsanlara vesaire harcamalara da ulaşmak mümkündür (BOA, TS.MA.d., Kutu Numaraları: 3862, 3863, 3865, 3866).

$\mathrm{Ne}$ var ki hanedanlık yaşantısıyla ilgili pek çok meseleye 1şık tutacak mahiyette olan bu defterlerden bir kısmı günümüze ulaşamadığı aşikârdır. Öte yandan ilgili arşivde yer alan konuyla ilişkili kayıtlar içerisinde de gerekli muhafaza şartları sağlanamadığından tahribata uğramış ve araştırmacıların kullanıma sunulamamış defterler de buluna bilmektedir. Bu husustaki dezavantaja rağmen mevcut ve ulaşılabilen kayıtlar üzerinden hanedan üyelerinin gelir ve gider durumları ortaya konulabilir. Mesela III. Mustafa'nın kızı Şah Sultan Hanım'ın hususî masraf defterleri üzerinden gelir-gider bilançosu, harcamaların yoğunlaştığı kalemler üzerinden iktisadi mahiyette bir analiz yapılabilir. Bu açıdan bakıldığında Devlet Arşivleri Başkanlığı'nın Topkapı Sarayı Arşivi Defterleri fonundan bulunan III. Mustafa'nın kızı Şah Sultan Hanım'ın hususî masraf defterlerinin ihtiva ettikleri bilgilerin mühim bir kıymeti olduğunu ifade etmek gerekmektedir. Bu defterler, Şah Sultan Hanım'ın, 1798-1803 yılları arasındaki masraflarını içermektedir (BOA, TS.MA.d., Kutu Numaraları: 3862, 3863, 3865, 3866).

İlgili arşivde yapılan incelemelerde Şah Sultan Hanım'ın hususî masraflarını içeren toplamda elli dört adet deftere ulaşılmıştır. Aslında beş yılı kapsayan bu defterlerin altmış adet olması gerekmektedir. Ancak söz konusu arşiv merkezinde gerçekleştirilen taramada bazı yıllara ait aylık masraf defterlerine ulaşılamamıştır. Bu durumun nedenini tam olarak izah edememekle birlikte ilgili kayıtlar ya günümüze ulaşmadan tahrip olmuş ya da Topkapı Sarayı Arşiv belgelerinin asıl merkeze nakilleri esnasında farklı bir kodla tasnif edilmiş olabilme ihtimalidir. Bu sebepledir ki incelenen dönemin bazı yıllarında toplam harcama miktarlarının eksik olduğu görülecektir.

Defterlerin tasnif ve kayıt işlemleri yapılırken H. 1213 (1798-1799) ve 1214 (17991800) yıllarına ait masraf defterlerinde aynı kutu numarasının kullanıldığı tespit edilmiştir (BOA, TS.MA.d., Kutu Numaraları: 3865). Araştırmaya dâhil edilen diğer yıllar ise müstakil olmak üzere her biri farklı bir kutu numarası ile tasnif edilmiştir (Hicri 1215, BOA, TS.MA.d., Kutu Numaras1: 3862; Hicri 1216, BOA, TS.MA.d., Kutu Numaras1: 3863; Hicri 1217, BOA, TS.MA.d., Kutu Numaras1: 3866). Mezkûr defterler, hicri takvim esas alınarak tutulmuştur. Ayrıca bu defterlerde bir sene içerisinde vukua gelen harcamalar, ay bazında kayıt altına alınmıştır. Defterlerin girizgâhında; masraf defterinin hangi yıl ve aya ait olduğu ifade 
edildikten ve Şah Sultan'1 öven kelimelerden sonra defterin Sultan'a ait olduğu zikredilmiştir. Hâkeza defterlerin tasdiki bizzat Şah Sultan tarafından yapıldığını gösteren mühür de sayfaların en alt kısmında yer almaktadır.

Defterlerin tertibinde rika yazısı kullanılmıştır. Harcamalar kayıt altına alınırken belli bir nizamın takip edildiği tespit edilmiştir. Bu bağlamda ilk kayıtların, daha çok her ay düzenli aralıklarla masraf yapılan kalemlerden oluştuğu anlaşılmıştır. Akabinde saraylar için yapılan muhtelif harcamalar ile Hanım Sultan'ın şahsi kullanımları için satın alınan eşyalar kayda geçirilmiştir. İncelenen dönem içerisinde harcama kalemlerine bakıldığında Şah Sultan'a verilen harçlıklar, çeşitli hizmetlerde bulunan kişilere ödenen aylıklar, İstanbul'da bulunan birtakım sarayların masrafları ve dokuma ürünlerinden oluştuğu tespit edilmiştir (Bkz: Grafik 1).

Grafik 1. Şah Sultan'ın harcama miktarlarının kalem bazındaki dağılımı (\%)

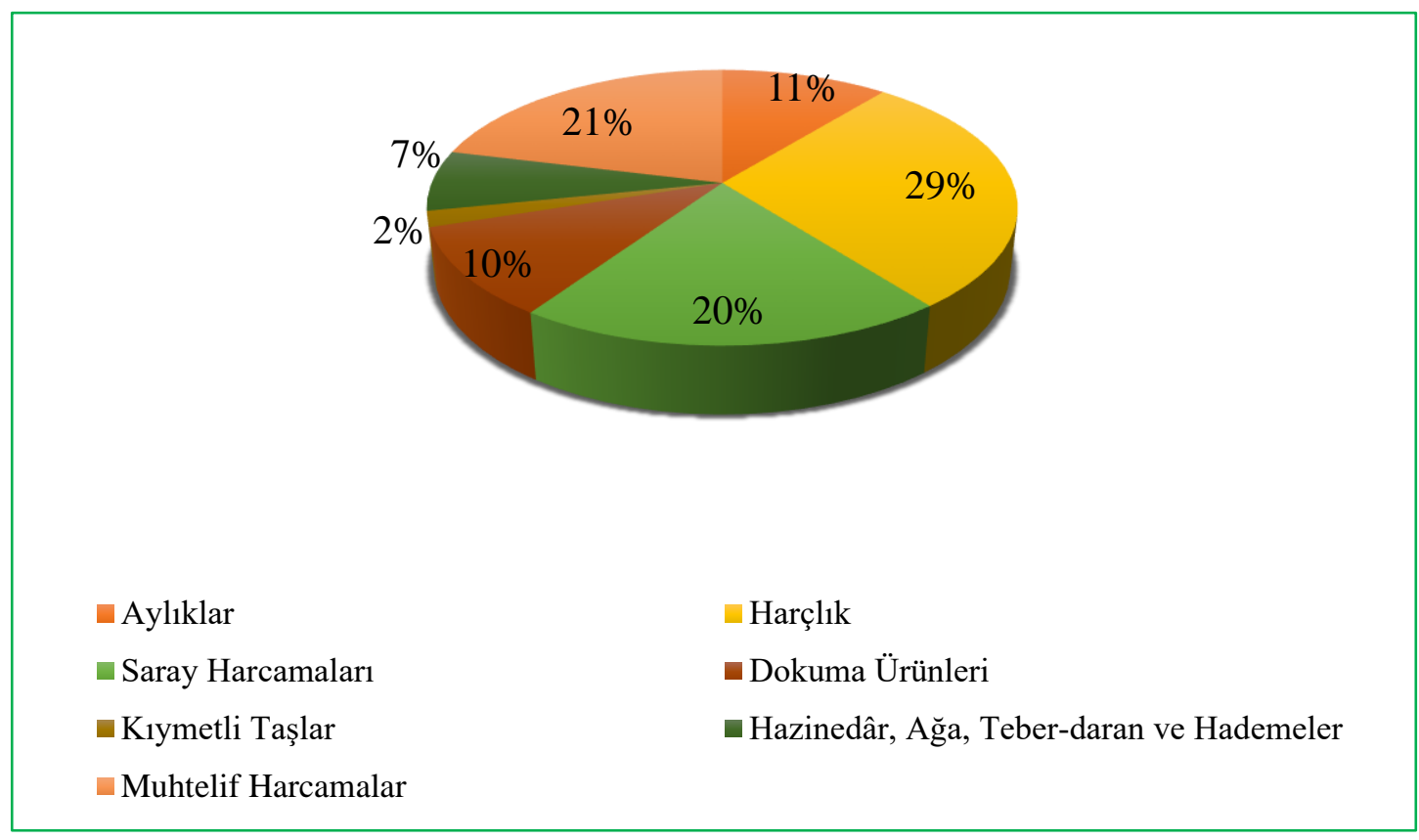

Kaynak: BOA, TS.MA.d., Kutu Numaraları: 3862, 3863, 3865, 3866.

Grafik 1'de görüldüğü üzere Şah Sultan'ın masraf dağılımı içerisinde harçlıkların önemli bir dilime (\% 29) sahip olduğu anlaşılmaktır. Gerçekten de incelenen defterlerin ekseriyetinde ay içerisinde Şah Sultan'a defalarca bir keselik (500 kuruş) ödemelerin yapıldığ 1 görülmüştür. Bu itibarladır ki harçlıkların toplam masraf içerisinde ağır basması beklenen bir sonuç olarak karşımıza çıkmaktadır. \% 20'lik dilimi teşkil eden saray harcamaları genellikle kömür, odun, mutfak, bahçıvan ve çeşitli tamir masraflarından oluştuğu anlaşılmıştır.

Akabinde \% 11'lik bir oran ile masraflar içerisinde azımsanmayacak derecede bir yer kaplayan aylıklar, Şah Sultan'a her ay ödenen meblağ ifade etmektedir. Yine Şah Sultan'a ve onun hizmetinde bulunan hazinedâr ustası, ağa, teber-daran ve hizmetçilere ödenen aylıklar dikkat çekmektedir. Bu masrafların miktarları genel olarak birbirine yakın olup her ay düzenli bir şekilde yapılan ödemeler arasında değerlendirilebilir.

Dokuma ürünleri bağlamında yapılan harcamalara konu olan ürünlerin envai şallar, alaca, atlas, bürümcek, basma, çuhâ, çitâri, cânfes, diba, Frenk bezi, Hint kumaşlar, samur ve kakum kürkler, kaban, kaput, hatâyî, savâi gibi emtiadan oluştuğunu ifade etmek gerekir. Bunlarda \% 10'luk dilime denk düşmüştür. Kıymetli taşlar arasında ise Şah Sultan tarafından tercih edilen ürünler içerisinde yakut ve elmas yüzükler, mücevher iğneler, kuşaklar, avizeler, elmas bilezikler, elmas ve demir küpeler yer almıştır. Bu ürünlerde toplam harcamanın \% 2'si oluşturmuştur. Masraf kayıtları içerisinde yer alan ve muhtelif kalemlerden oluşan ürünlerin 
miktarı \% 21 gibi önemli bir orana tekabül etmektedir. Masraf defterlerinin muhtevasını göstermek maksadıyla oluşturulan yukarıdaki grafikte gösterilen tüm kalemlerle ilgili detaylı bilgiler çalışmanın ilgili bölümlerinde izah edildiğinden burada tekrardan açıklama yapmaya lüzum görülmemiştir.

Öte yandan masraf defterlerinde harcama kalemlerinin kıymet bakımından değerleri kuruş cinsinden ifade edilmiştir. Haddizatında akçe ve dirhemin de kullanıldığı kalemler de tespit edilmiştir. Ancak bu kalemlerin de toplam cinsinden değerleri en sonda kuruş olarak hesaplanmıştır. Defterde bir kese, beş yüz kuruşa denk tutulmuştur. Bu kapsamda bir ay zarfında yapılan harcamaların toplam kıymetleri verildikten sonra en alt kısımda kaç keseye tekabül ettiği de beyan edilmiştir. Masraf defterlerinde yer alan bazı kalemlerin tob, zira', kıyye ve çeki gibi ölçü birimlerine göre hesaplandığı tespit edilmiştir.

Netice itibarıyla araştırmada kullanılan masraf defterleri ışığında Şah Sultan'ın harcama kalemlerini ve pek çok ayrıntıyı ortaya çıkartmak mümkün olabilmektedir. Hatta benzer defterler üzerinden yapılacak tarih araştırmaları neticesinde farklı dönemlere ait hanedanlığın sosyo-iktisadi hayatı karşılaştırmalı olarak analiz edilebilir. Bu itibarlıdır ki masraf defterleri, Osmanlı hanedanlığının sosyo-iktisadi yaşamında pek çok ayrıntıyı ortaya çıkartması bağlamında tarih araştırmalarında oldukça kıymetli bir alan tuttuğunu söylemek hiç de abartı olmayacaktır.

\section{Masrafların Niteliği ve Miktarları}

Osmanlı padişahlarına, hanım sultanlara veya kızlarına tahsis edilen meblağlar ve buna binaen yaptıkları harcamalar, her devirde dikkat çekici olmuş ve idarî bir müessese tarafindan kontrol edilerek kayıt altına alınmaya çalışılmıştır. Mesela Osmanlı padişahlarına ait gelirleri ve bunlardan yaptıkları harcamaları kontrol eden birim Ceyb-i Hümâyûn hazinesi olmuştur (Sahillioğlu, 1993, s.465). Klasik dönemde padişahın cebi olarak da nitelendirilen bu müessesenin ismi, 1847'de Sultan Abdülmecit'in almış olduğu bir kararla "Hazine-i Hassa" şeklinde değiştirilmiştir (Terzi, 2000, s.20). Her iki birim tarafından tutulan kayıtlardan padişahlara tahsis edilen gelirlerin niteliği, padişahların hizmetinde bulunan kişilere tahsis edilen aylıklar, hediyeler ve in'amlar, dini ay ve günlerde halka sunulan ihsanlara ulaşmak mümkün olabilmektedir (Işıktaş, 2013; Tunç 2013; Yolal, 2013; Küçükali, 2018).

Yine hanım sultanlar ve kızlarına ait hususi masraf defterleri üzerinden onların gelirgider dengesi ve harcamaların yoğunlaştığı kalemler incelenebilmektedir. Mesela Sultan III. Mustafa'nın başkadınlarından olan Âdilşah Sultan'ın masraflarını inceleyen Bozkurt, Hanım Sultan'ın masraflarının yoğunlaştığı kalemleri giyim, takı ve süs eşyası, gıda ürünleri, mutfak gereçleri, ev eşyası ve diğerleri şeklinde sınıflandırmıştır (Bozkurt, 2016, s.18). Mezkûr çalışmada ele alınan Şah Sultan'ın masrafları da bu nitelikte değerlendirilebilir. Dolayısıyla tarihsel süreçte Osmanlı padişahları, hanım sultanları veya kızlarının masraflarının yoğunlaştığ harcama kalemlerine bakıldığında ekseriyetle benzer olduğu söylenebilir. Öte yandan padişah hanımları ve kızlarına ait muhallefat veya çeyiz defterleri incelendiğinde tespit edilen ürünlerin de harcama kalemleriyle özdeşleştiği görülecektir (Işıktaş, 2020a).

Şah Sultan'ın masraf kayıtları iki şekilde incelenebilir. Bunlardan ilkini gelirler, ikincisini ise giderler olarak sınıflandırmak mümkündür. Gelirler kapsamında aylıklar ve harçlıklar yer alırken giderler ekseriyetle saray harcamaları, teberdaran, ağa ve hademelere ödenen aylıklar, kıymetli ziynet eşyalarına tahsis edilen meblağlar, dokuma ürünleri için harcanan miktarlar ile çeşitli eşyaların alımdan oluşmaktadır. Bu itibarladır ki incelenen dönem içerisinde Şah Sultan Hanım'ın masraf defterleri içerisinde yer alan harcama kalemleri, yalnızca onun şahsi ürünlerinden değil aynı zaman da hanesinin ve mahiyetinde bulunan kişilerin ihtiyaçlarını karşılamak üzere satın alınmış mallardan oluşmakta ve her bir kaleme harcanan meblağ da farkl11ık göstermektedir (Bkz: Grafik 2). 


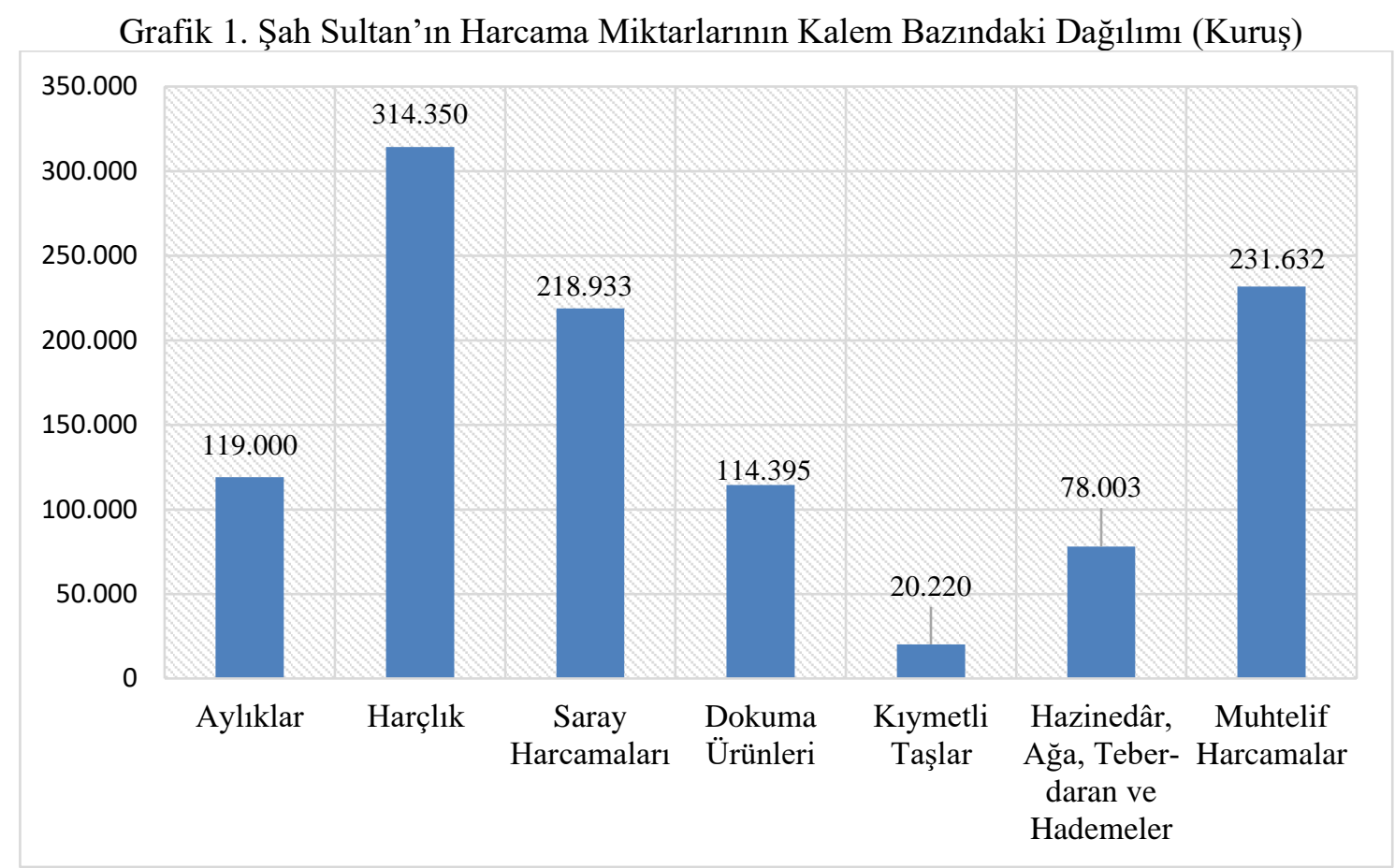

Kaynak: BOA, TS.MA.d., Kutu Numaraları: 3862, 3863, 3865, 3866.

Grafik 2'de gösterildiği üzere Şah Sultan'ın masraf defterleri içerisinde ön plana çıkan gider unsuru harçlık mahiyetinde ödenen meblağlardır. Bu miktar, ekseriyetle bir kese üzerinden yani beş yüz kuruş değerinde olmuştur. Muhtemeldir ki mezkûr ödemeler, bir defaya mahsus bir şekilde yapılmamış ihtiyacın hâsıl olduğu durumlarda harçlık tahsisleri ay içerisinde yeniden yapılmıştır. Çünkü incelenen defterlerde bu türden ödemelerin birden çok defa kayıt altına alındığı görülmüştür. Bilhassa dini ay ile günlerde ihsanlarda buyurmak ve Şah Sultan'1 ziyarete gelen yüksek mevkili devlet adamlarına çeşitli hediyeler ve ikramlar sunmak amacıyla harçlık cinsindeki ödemelerin arttığı tespit edilmiştir.

Aslında bu durum, Hanım Sultan'a has değildi. Osmanlı Devleti'nin diplomatik ananeleri içerisinde yer alan bir uygulamaydı. Çoğu Osmanlı padişahı, padişah eşleri ve kızları; kendilerini ziyarete gelen yüksek mevkili kişilere bu tür ihsanlar, hediyeler ve ikramlarda bulunmuşlardır. Hâkeza Osmanlı hanedanlığına teşrif edenler de padişahlara, valide sultanlara ve çocuklarına kıymetli hediyeler getirdikleri de bilinmektedir (Öztürk, 2007; Kiel 2007, Mert, 2007). Bundan dolayı Şah Sultan'ın bu türdeki faaliyetleri ve harcamaları karşılığında harçlık alması her halde diplomatik kültürün bir neticesi olarak tezahür etmiştir. Böylece incelenen beș yıllık safhada Hanım Sultan'a harçlık adıyla ödenen toplam para 314.350 kuruş olarak hesaplanmıştır.

Harçlıklardan sonra harcama kalemleri bazında dikkat çeken bir diğer gider saray harcamalarıdır. Bu harcamalar belli başlı gider kalemlerinden oluşmaktadır. Bunlar arasında; İstanbul, Eyüb ve Kuruçeşme adlarıyla nitelendirilen sarayların/dairelerin tamir masrafları, bahçıvanlık masrafları, sarayların ısınma ve mutfak giderleri yer almaktadır. İncelenen dönemin tüm ayları içerisinde bu tür giderlerin olduğunu ifade etmek gerekir. Toplamda 218.933 kuruşa tekabül eden bu masraflar, önemli gider kalemleri arasında yer aldığı ilgili grafikten de anlaşılmaktadır.

Masraf kalemleri içerisinde değerlendirilen bir diğer harcama kalemi, Hanım Sultan'ın aylık maaşıdır. Hicri 1213 (1798-1799) yılında 2.000 kuruş olarak ödenen bu miktar, Hicri 1214 yılının zilkade (Mart-1800) ayından itibaren beş yüz kuruş zam yapılarak aylık 2.500 kuruş üzerinden ödenmeye başlanmıştır. Maaş tahsisi kapsamında toplamda 119.000 kuruşluk bir ödeme yapılmış olup bu miktar yekûn masrafin (1.099.785 kuruş) \% 10'na tekabül etmektedir. 
Şah Sultan'ın harcama kalemleri içerisinde dokuma ürünlerin de önemli bir paya sahip olduğunu ifade etmek gerekir. İlgili kayıtlarda geçen dokuma malları şu şekilde sıralanabilir: alaca, atlas, bürümcek, basma, çuhâ, çitâri, cânfes, diba, frenk bez, hind kumaşlar, samur ve kakum kürkler, kaban, kaput, hatâyî, savâi, çiçekli ve çeşitli motiflerde şallardır. Bu ürünler; adet, tob, zirâi veya arşını ölçü birimine göre satın alınmıştır. Dönemin iktisadi şartlarına göre oldukça pahalıya mal edilen bu ürünlerin, toplam maliyeti 81.174 kuruştur. Ayrıca içlik ve yatak örtüsü takımları satan yağlıkçı (Pakalın, 1972, s.600) olarak nitelendirilen esnaflara toplamda 33.220,5 kuruşluk bir ödeme yapılmıştır. Böylece dokuma ürünleri kapsamında toplam harcama miktarı 114.394,5 kuruşa ulaşmıştır.

Şah Sultan'ın masrafları içerisinde önemli bir yer tutan harcama giderini de hazinedâr ustası, ağa, teberdaran ve çeşitli görevlerde çalıştırılmak suretiyle sarayda bulunan hademelere ödenen meblağlar oluşturmaktadır. Bu giderler içerisinde örnek vermek gerekirse hem Valide Taşlığı hem de Cariyeler Taşlığı dairesinin muhafazasından sorumlu olan hazinedâr ustasına (Ortaylı 2008, s. 190; Özbilgen, 2011, s. 196) her ay 50 kuruşluk bir maaş verilmiş olup bu miktarın incelenen dönem içerisinde değişmediği tespit edilmiştir. Yine saadetlü Cemile Hanım'a 15 kuruş maaş verilmiş bu meblağ da değişmeden devam etmiştir. Ağa, teberdaran ve hademeler ödenen aylıkların ise 700 ile 840 kuruş arasında değişkenlik gösterdiği görülmüştür. Bunlar birlikte bahçıvan ve muhtelif işlerle görev yapan kişilere de cüzî oranda maaşlar ödenmiştir. Bu kalemler içerisinde yer alan tüm giderler için toplamda 78.003 kuruşun harcandığ 1 tespit edilmiştir.

Şah Sultan'ın şahsi harcamalar niteliğinde değerlendirilen masraf kalemlerinden birisi ziynet eşyalarıdır. Bilindiği üzere valide sultanlar, hanım sultanlar ve gözdelerin sarayın en güzel ve gösterişli mücevherlerini tercih etmişlerdir. Saray kadınlarının beğenisi ve isteği üzerine mamul edilen mücevherat ve takılar, saray kadınlarının nazarında gücün, zenginliğin, ihtişamın ve asaletin simgesi olarak kullanılmıştır (Ekinci, 2019, s. 54).

Osmanlı saray kadınlarının ilgi gösterdikleri ve kullanıma önem verdikleri mücevherat ve takıların başında altın, elmas, yakut, zümrüt, gümüş veya inciden yapılmış yüzük, küpe, bilezik, gerdanlık, halhal, iğne ve kuşak gibi envai ürünler gelmiştir (İrepoğlu, 2012). Bu bağlamda Şah Sultan'ın kullandığı mücevherat ve takı ürünleri arasında; yakut, zümrüt ve elmas yüzükler, pırlanta ve elmas başlı iğneler, mücevher kutular, mücevher kuşak, altın bileziklerle demir ve elmas küpeler yer almıştır. Bu ürünlerin toplam maliyeti 20.220 kuruş olarak hesaplanmıştır.

Öte yandan kıymetli taşların alım-satımları ve tamir işlemlerinin dönemin kuyumcu esnaflarından biri olan Kigorak (?) tarafindan yapıldığı ve Şah Sultan'ın ziynet eşyalarını ekseriyetle bu kuyumcudan aldığı anlaşılmıştır. Buradan hareketle Şah Sultan gibi muhtemeldir ki diğer saray kadınları da mücevherat ve takı ürünlerini satın alırken ya da mamul ettirirken zanaat işlerinde kabiliyetli olan gayrimüslim zanaatkârları tercih ettiklerini gösterir.

Muhtelif harcamalar adı altında gösterilen meblağ, farklı gider kalemlerinden oluşmaktadır. Bu giderler içerisinde; Şah Sultan'a yazlık mahiyetinde ödenen bir keselik miktarlar, Şah Sultan'a buyrulan bir keselik -beş yüz kuruş değerindeki- altınlar, sarayda Sultan Hanım'ın hizmetinde çalıştıılmak üzere satın alınan cariye bedelleri, Şah Sultan'ın mukataaları cebelüsü için Hazine-i Amire'ye teslim olunan miktarlar, çeşitli vakıflara verilen miktarlar, dini günlerde fakir ahaliye sunulan ihsanlar ile birtakım giderler yer almaktadır. Bu itibarladır ki ele alınan dönem içerisinde mezkûr harcama kalemlerinin toplam maliyeti 1.099.785 kuruş olarak hesaplanmıştır. Bu meblağın yıllar bazındaki dağılımları ise farklılık göstermiştir (Bkz: Grafik $3)$. 
Grafik 2. Şah Sultan Hanım’ın yapmış olduğu harcamaların yıllar bazındaki dağılımı (kuruş)

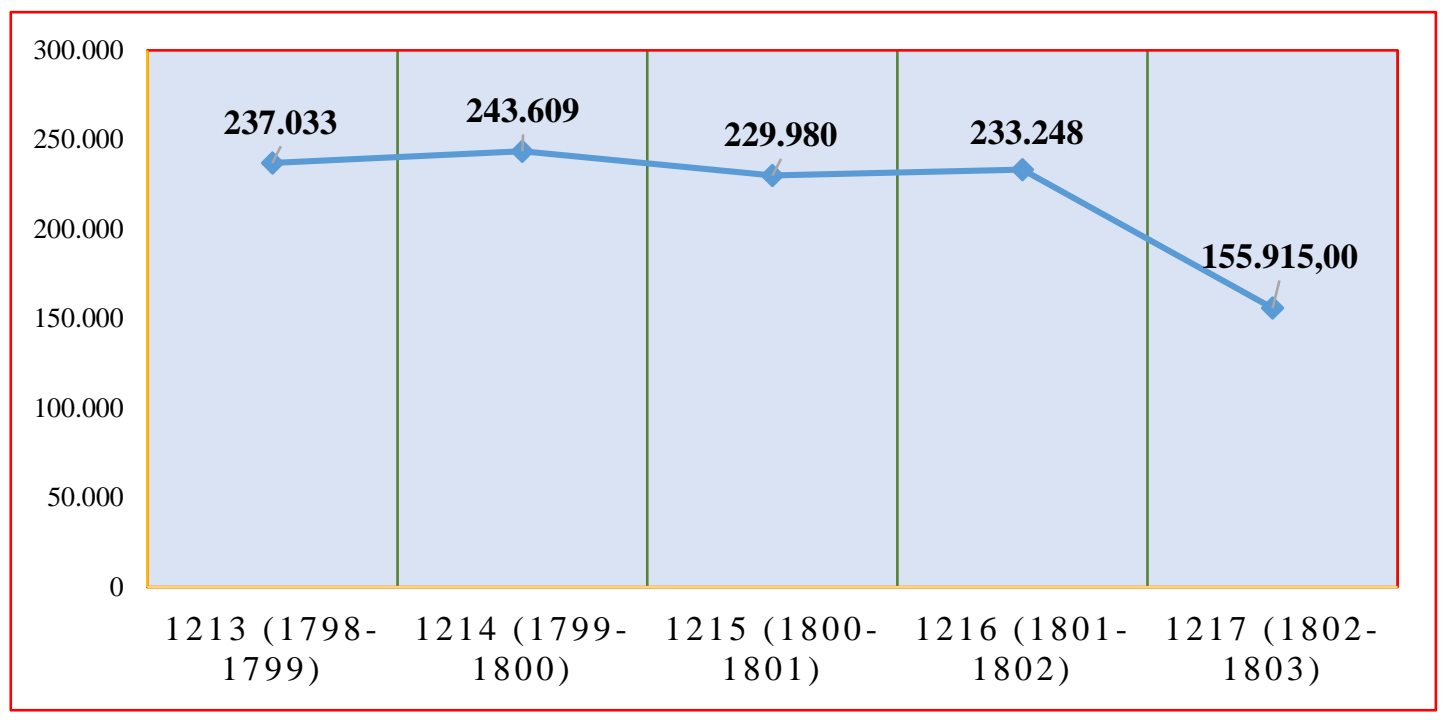

Kaynak: BOA, TS.MA.d., Kutu Numaralar1: 3862, 3863, 3865, 3866.

Grafik 3'e bakıldığında; iki önemli husus göze çarpmaktadır. Bunlardan ilki, Şah Sultan'ın masraflarının yıllar itibarıyla homojen bir dağılım göstermesi; ikincisi ise hicri 1217 (1802-1803) yılı masraflarının önemli bir oranda azalmasıdır. Gerçekten de hicri 1213 ile 1216 (1798-1802) yılları arasında masrafların dağılımlarına bakıldığında birbirine yakın bir harcama oranın yapıldığı anlaşılmaktadır. Bu durum da Şah Sultan'ın gelir-gider bilançosunda ciddi bir değişmenin olmadığını ve harcamaların benzer kalemler üzerinde yoğunlaştığını göstermektedir.

Tabi her dönem içerisinde harcama miktarlarının yoğunlaştığı aylar da farklılık arz ettiğini ifade etmekte fayda vardır (Ekler: Grafik 6-10). Öte yandan mezkûr dönemler içerisinde Şah Sultan'ın gelir-gider bilançosunda en yüksek masraf miktarını 243.609 kuruşla hicri 1214 (1799-1800); en az ise 155.915 kuruşla hicri 1217 (1802-1803) senesine ait olduğu görülmektedir.

İlgili grafikte dikkat çeken bir diğer husus, hicri 1217 (1802-1803) senesine ait harcama miktarının bir önceki yıllara nazaran keskin bir şekilde azalmasıdır. Öncelikle bu azalışın Şah Sultan'ın gelir-gider kalemlerinden kaynaklanmadığını ifade etmek gerekir. Bu düşüşün meydana gelmesinde iki ihtimal üzerinde durulmaktadır. Bunlardan ilki, Şah Sultan'ın bu yıla mahsus masraf kayıtları içerisinde bazı aylara ait verilere ulaşılamamış olmasıdır. Diğeri ise Şah Sultan'ın bu yılda vefat etmesidir. Bu düşüşte etkili olabileceği düşünülen ikinci ihtimalde birtakım çelişkiler göze çarpmaktadır. Şah Sultan'ın vefat tarihiyle ilgili literatürde bulunan kaynaklar üzerinde yapılan incelemelerde ölüm yılı hicri 1216 yılının zilkade ayı "1802Mart/Nisan" olarak gösterilmektedir (Uluçay, 2001, s. 154).

Yine bir başka kayıtta ise 1803 yılına işaret edilmiştir (Atalar, 1981, s.448). Ancak masraf defterleri doğrultusunda yapılan araştırmalarda Şah Sultan'ın hicri 1217 senesinin ramazan (Aralık/Ocak 1802-1803) ayında aylık aldığ 1 tespit edilmiştir. Yani o tarihlerde Hanım Sultan'a aylık verildiğinden onun hayatta olduğu düşünülmektedir. Bu nedenledir ki Sultan'ın ölüm yılının hicri 1217 senesinin ramazan ayı içerisi veya sonrasında olduğu ihtimalini güçlendirmektedir. Zira aynı yılın şevval, zilkade ve zilhicce aylarına ait masraf defterlerinin olması bunu destekler niteliktedir. Ayrıca safer ayına ait masraf defterine ulaşılamamıştır. Bu itibarladır ki ilgili yılda husule gelen masrafın azalış göstermesinde iki ihtimalin de etkili olduğu söylenebilir. 


\section{Emtia ve Fiyat İlișkisi}

Hanedan üyelerine ait masraf defterleri, gelir-gider bilançosunun yanı sıra dönemin ticaretine konu olan emtia listesi ve kıymetlerinin tespit edilmesinde son derece önemli bir yere sahip olduğunu söylemek mümkündür. Bu bağlamda incelenen defterler içerisinde birtakım emtia listesine ulaşılmıştır. Bu emtia, iki grup içerisinde sınıflandırılmış ve sosyo-iktisadi bağlamda bir değerlendirmeye tabi tutulmuştur. Bunlardan ilki, dokuma ürünleridir. Ekseriyetle şal çeşitleri, bürümcek, kadife, kürk, keçe, çuhâ, çitari, gezi, canfes, dîbâ ve savâ'î gibi muhtelif ürünlerinden oluşmaktadır. Ürünler fiyatlandırılırken öncelikle adet, arşın, tob, zirâ veya parça gibi farklı ölçü birimlerine göre hesaplandırılmış akabinde cinsi ve kalitesine göre kıymetlendirilmiştir. $\mathrm{Bu}$ nedenledir ki aynı ürünün farklı fiyat aralıklarında satın alındığı görülmüş̧ür. Ayrıca aynı türden ürünlerin fiyat aralıklarında kayda değer bir farklılık olduğu anlaşılmıştır (Bkz: Grafik 4).

Grafik 3. Masraf defterlerinde yer alan dokuma emtiasının kıymetleri (kuruş)

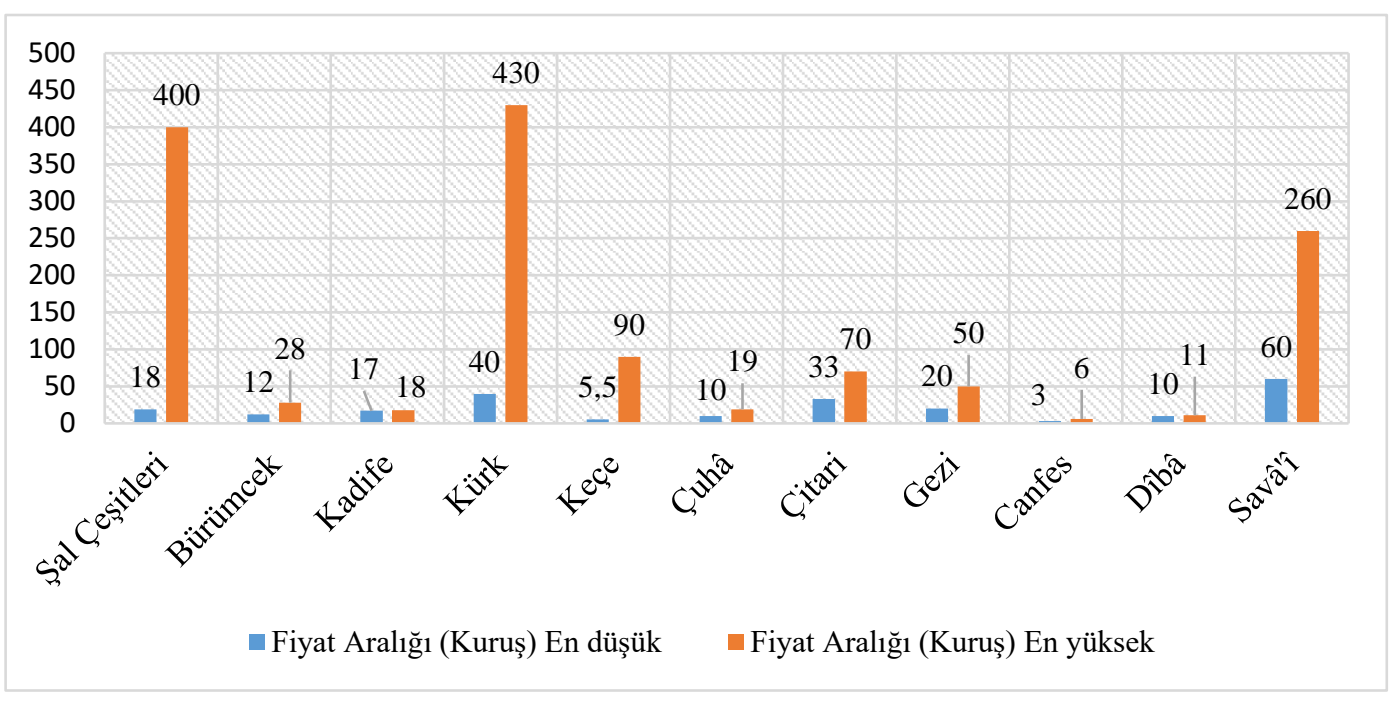

Kaynak: BOA, TS.MA.d., Kutu Numaralar1: 3862, 3863, 3865, 3866.

Yukarıdaki grafikte dokuma ürünlerinin en düşük ile yüksek değerleri gösterilmiştir. Ürün bazında en yüksek fiyat üzerinden kıymetlendirilen emtia kürk olmuştur. Samur ve kakum şeklinde tarif edilen bu kürkler, kürk ticareti kapsamında en kıymetli cinsler arasında gösterilmektedir (Tekin, 2002, s. 757). Kürkler; 40, 45, 60, 115, 120, 125 veya 430 kuruşa satın alınmıştır. Muhtemeldir ki ürünün kalitesine göre fiyat aralığı da farklılık göstermiştir.

Grafik 4'te dikkat çeken bir diğer ürün çeşidi ise şallardır. Şallar, sade çiçekli, düz, âlâ, sarı, turuncu, lacivert, beyaz, çıkılı gibi çeşitli motiflerle nitelendirilmiştir. Bunlar içerisinde en ucuz şal 18 kuruş olup, 150, 160, 170, 190, 200 ve 400 kuruş gibi farklı fiyat aralıkları ile satın alınmıştır. Şal fiyatlarının bu kadar yüksek olması hem düşündürücü hem de dikkate şayan bir durum olmuştur. Çünkü ele alınan döneme yakın şal fiyatları incelendiğinde daha makul fiyatların Osmanlı pazarlarında ticarete dâhil edildiği söylenebilir. Mesela 1800 yılına ait Diyarbakır gümrüğüne getirilen malların iç tarife ve alım-satım değerlerinde bir tob şalın fiyatı 30 kuruş, içlik bir şal 10-15 kuruş, Ankara şalı 60 ile 100 kuruş arasında gösterilmiştir (Işıktaş, 2020b, s. 126). Bu itibarladır ki Şah Sultan'ın satın aldığı içlik şalların oldukça yüksek meblağlara alınmış olması manidar bir sonuç olarak ortaya çıkmıştır.

Yine kıymet bakımından dikkate nazır olan diğer ürün ise savâ'î olmuştur. Bir kumaş türü olan savâî, Şah Sultan Hanım'ın en çok tercih ettiği emtia arasında yer almıştır. Bu üç ürünün diğer emtiaya nazaran oldukça pahalıya mal edildiği söylenebilir. Öteki ürünler, Hanım Sultan tarafından sıklıkla tercih edilmekle birlikte fiyat aralıklarının dengeli bir şekilde seyir gösterdiği ifade edilebilir. 
Dokuma ürünlerinin yanı sıra Hanım Sultan'ın satın aldığı bir diğer emtia grubunu ziynet eşyaları oluşturmaktadır. Bu emtia arasında; yakut ve elmas yüzükler, mücevher iğneler, kuşaklar, avizeler, elmas bilezikler, elmas ve demir küpeler yer almaktadır. Bu ürünlerin de fiyat aralığı ürünün cinsi ve kalitesine göre değişkenlik göstermektedir (Bkz: Grafik 5).

Grafik 4. Masraf defterlerinde yer alan ziynet eşyasının kıymetleri (kuruş)

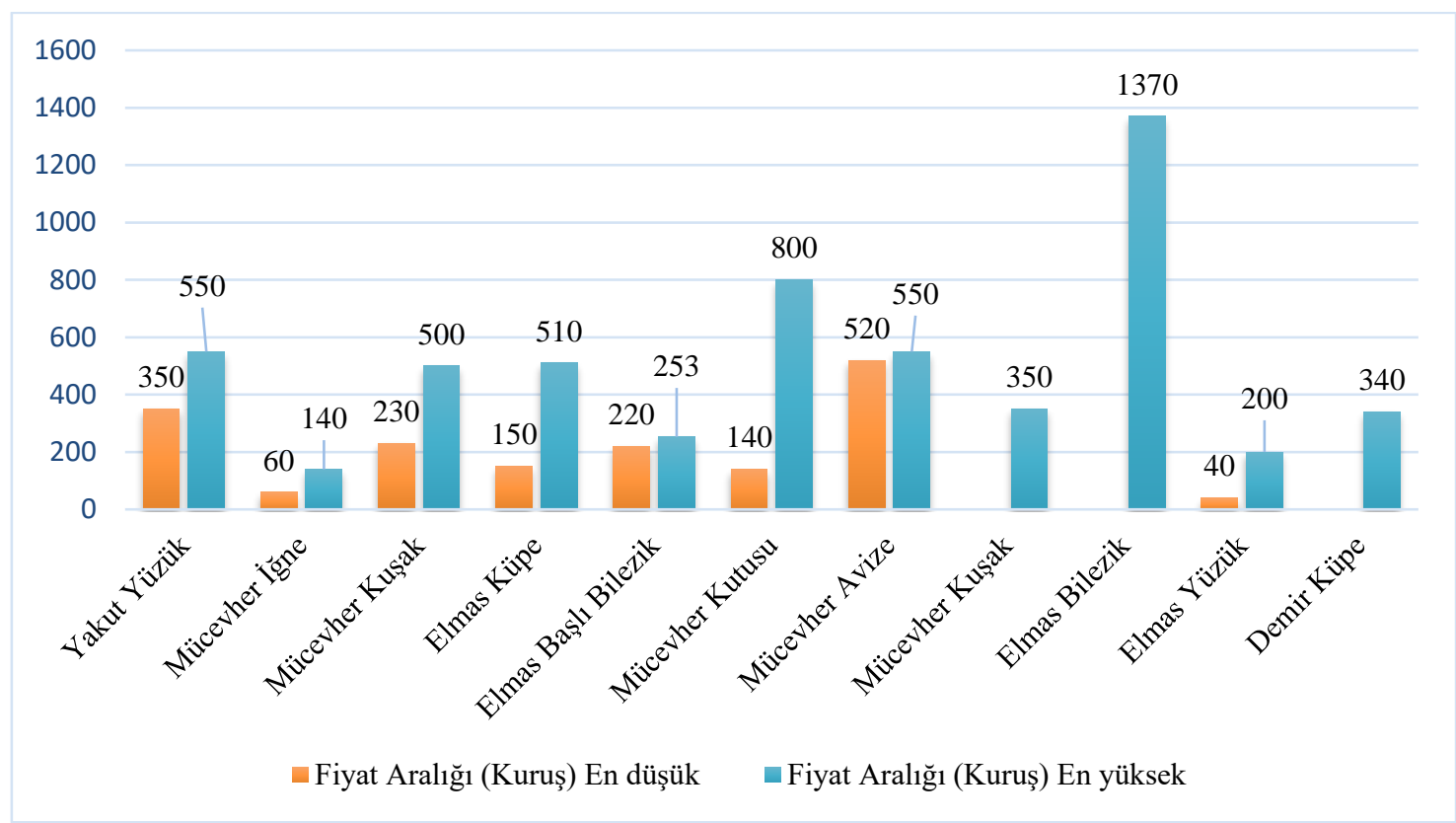

Kaynak: BOA, TS.MA.d., Kutu Numaraları: 3862, 3863, 3865, 3866.

Grafik 5'e göre ziynet eşyalarının fiyat aralıkları incelendiğinde ürünler arasındaki değer farkının epeyce fazla olduğu görülmektedir. Aslında aynı ürünün farklı fiyat aralıklarında satışa sunulmasının temel sebebi -yukarıda izah edildiği üzere- ürünün işçilik ve kalitesinden kaynaklansa olsa gerektir. Mesela mücevher kutusu olarak satın alınan ürünleri en düşüğü 140 , en yükseği 800 kuruşa satın alınmıştır. Bununla birlikte 520, 570, 650 ve 710 kuruşa alınan mücevher kutuları bulunmaktadır.

Yine elmas küpelerin biri 150 diğeri 510 kuruşluktur. Şah Sultan'ın elmas ve yakut yüzükleri tercih ettiği, yakut yüzüklerin elmastan daha kıymetli olduğu anlaşılmaktadır. Hâkeza bilezik bağlamında elmasın ön planda olduğu görülmektedir. Bu bağlamda grafikte dikkat çeken elmas bileziğin adet bazındaki sayısı bir olup bunun da maliyeti 1370 kuruş olarak kayda geçmiştir. Keza bir adet olan demir küpe 340, mücevher kuşak ise 350 kuruşa mal edilmiştir.

Şah Sultan'ın satın aldığı ürünler kıyaslandığında oldukça önemli birkaç hususa vurgu yapılabilir. Bu minvalde Şah Sultan'ın dokuma ve ziynet eşyalarını satın alırken oldukça pahalı ürünleri tercih ettiği anlaşılmaktadır. Ayrıca bazı dokuma ürünlerine ödenen meblağların ziynet eşyasından daha yüksek olduğu gözlemlenmektedir. Ürün-fiyat ilişkisi dikkate alındığında Şah Sultan'ın bu iki kaleme sarf ettiği meblağa bakılır ise Hanım Sultan'ın muazzam bir alım gücüne sahip olduğu ifade edilebilir.

\section{Sonuç ve Öneriler}

Kuruluşundan yıkılışına kadar takip ettiği politikalar ile birçok döneme damga vuran Osmanlı Devleti, aynı zamanda hanedanlık yaşantısıyla da hayli ilgi çekmekte ve pek çok araştırmaya konu olmaktadır. Ne var ki yüzeysel veya ilgi çekici yönleriyle ortaya konulan ya da konulmaya çalışılan Osmanlı hanedan üyelerinin sosyo-iktisadi yaşamı derinlemesine inceleme gerektiren bir konu olmakta ve güncelliğini korumaktadır. Bu düşünceden hareketle padişahlar, valide sultanlar, hanım sultanlar ve şehzadelerin sosyal yaşamlarını inceleyen 
çalışmaların daha da artacağı ve konuya ilişkin daha spesifik meselelerin ele alınması gerektiği kanaati hâkim olmuştur. Bu itibarladır ki Hanım Sultanların tüketim kalıpları üzerinden yaşam kültürleri ve anlayışları hakkında fikir sahibi olmak noktasında masraf defterlerinin ehemmiyeti bu çalışmayla bir kez daha ortaya konulmaya çalışılmıştır.

İncelenen belgeler doğrultusunda Şah Sultan'ın yaşam tarzı, tercih ettiği tüketim kalıpları, gündelik yaşantısı, hanedan üyeleriyle olan ilişkisi, gelir ve gider kalemlerine ilişkin birtakım çıkarımlara gidilmiştir. Bu bağlamda öncelikle Şah Sultan'da -muhtemeldir ki- diğer Hanım Sultan'lar gibi gösteriş ile perçinleştirilmiş bir yaşam felsefesine sahip olduğu tahmin edilmektedir. Zira tercih ettiği tüketim kalıpları ve çeşitli nedenlerle mahiyetinde bulunan kişilere yapmış olduğu ihsanlar dikkate alındığında bu tespitin oldukça yerinde olduğu anlaşılmıştır.

Şah Sultan'ın tüketim kalıpları noktasında şahsi kullanımları için satın aldığı dokuma ve mücevherat ürünlerine toplam masrafın \% 12'sine (134.615 kuruş) tekabül eden kayda değer bir miktarda harcama yaptığ 1 görülmüştür. Ayrıca kıymetli ve kaliteli ürünleri tercih eden Hanım Sultan'ın muazzam bir alım gücüne de sahip olduğu anlaşılmıştır. Hiç kuşkusuz bunda Şah Sultan'a tahsis edilen aylıklar, harçlıklar ve çeşitli mukataaların gelirlerinin etkili olduğu düşünülmektedir.

Şah Sultan'ın gündelik yaşantısı bağlamında ikamet ettiği daire/sarayların idaresi ve kontrolüyle meşgul olduğu görülmüştür. Gerek Sultan III. Mustafa gerekse valide sultanların kendisini ziyaretlerinde izzet-i ikram adına büyük hazırlıklar yapıldığı, hediyeler sunulduğu ve bunun içinde ek harçlıkların ödendiği tespit edilmiştir. Yine mutfak, koruma, araba sürücüleri, bahçıvanlık ve diğer saray işleriyle ilgilenen birçok hademe ve cariyenin Hanım Sultan'ın gündelik yaşantısında etkin bir şekilde rol oynadıkları görülür.

Öte yandan Hanım Sultan'ın masraflarının yıllar itibarıyla dağılımlarında birbirine yakın bir harcama oranına sahip olduğu kanaatine ulaşılmıştır. Yani Şah Sultan'a yapılan harcamaların yıl bazındaki ortalama miktarının 220.000 kuruşa yakın olduğu hesaplanmıştır. Bu meblağ üzerinden hareketle dönemin sosyo-iktisadi hayatı mukayese edildiğinde saray kadınları ile halkın gündelik yaşantısı ve tüketim kalıpları arasında kayda değer bir oranda farkın olduğu çıkarımına varılmıştır. Zira Hanım Sultan'a yıl içerisinde harçlık ve aylık mahiyetinde verilen paralar, dokuma ve ziynet eşyalarına ödenen meblağlar halkın temel tüketim ürünleri arasında yer alan un, şeker, yağ, et ve dokuma fiyatlarıyla mukayese edildiğinde saray kadınlarının ciddi miktarlarda bir harcama yaptıkları tahmin edilmektedir.

Diğer taraftan Hanım Sultan'ın yıllar bazındaki gelir-gider bilançosunda ciddi bir değişmenin olmadığını ve harcamaların benzer kalemler üzerinde yoğunlaştığı söylenebilir. Şah Sultan'ın masraf defterleri arasında yer alan ve harcama kalemlerinin başında; ayliklar, harçlıklar ve çeşitli mukataaların cebelüsü için Hazine-i Amire'ye teslim olunan meblağlar, saray harcamaları, teberdaran, ağa ve hademelere ödenen aylıklar, kıymetli ziynet eşyalarına tahsis edilen meblağlar, dokuma ürünleri için harcanan miktarlar ile muhtelif eşyaların yer aldığı anlaşılmıştır.

$\mathrm{Bu}$ çalışmadan hareketle Osmanlı saray kadınlarının gelir ve gider kalemleri üzerine mikro da olsa sosyo-iktisadi mahiyette birtakım analizler ortaya konulmaya çalışılmıştır. Muhakkak ki bu konu ile ilgili incelenmeyi bekleyen birçok mesele bulunmaktadır. Mesela saray kadınlarının borç ilişkileri, terekeleri ve mukataa gelirleri gibi konular araştırmacıların ilgisini beklemektedir. Bu hususta yapılacak çalışmalarla Osmanlı saray kadınlarının yaşantısı ve sosyo-iktisadi durumları üzerine daha ayrıntılı bilgilere ulaşmak mümkün olacaktır. 


\section{Kaynakça}

Akgündüz, A. (2000). İslam hukukunda kölelik cariyelik meselesi Osmanlı'da harem. İstanbul: Osmanlı Araştırmaları Vakfı.

Akyıldız, A. (2019). Saray harem ve mahrem. İstanbul: Timaş Yayınları.

Atalar, M. (1981). Osmanlı padişahları. Ankara Üniversitesi İlahiyat Fakültesi Dergisi, 24(1), Ocak, 425-460.

BOA. (Başkanlık Osmanlı Arşivleri) TS.MA.e. (152), (2).

BOA. TS.MA.e. (Topkapı sarayı müze arşivi evrakı).:46, (5).

BOA. TS.MA.e. (Topkapı sarayı müze arşivi evrakı).(151), (35).

BOA. TS.MA.d. (Topkapı sarayı müze arşivi defterleri). (2631).

BOA. TS.MA.e. (Topkapı sarayı müze arşivi evrakı). (151), (37).

BOA. TS.MA.e. (Topkapı sarayı müze arşivi evrakı). (46), (8).

BOA. TS.MA.d. (Topkapı sarayı müze arşivi defterleri). (3862).

BOA. TS.MA.d. (Topkapı sarayı müze arşivi defterleri). (3863).

BOA. TS.MA.d. (Topkapı sarayı müze arşivi defterleri).(3865).

BOA. TS.MA.d. (Topkapı sarayı müze arşivi defterleri). (3866).

Bozkurt, F. (2016). III. Mustafa dönemine ait bir kadınefendinin masraf defteri. İstanbul: Okur Kitaplı̆̆1.

Cenkmen, E. (1948). Osmanl sarayl ve klyafetleri. İstanbul: Türkiye Yayınevi.

Ekinci, C. (2019). Osmanlı sarayında ve Osmanlı ümerası arasında altın ve mücevher kullanımı. Pamukkale Üniversitesi, Sosyal Bilimler Enstitüsü Tarih Anabilim Dalı, (Yayınlanmamış yüksek lisans tezi), Denizli.

Işıktaş, E. (2013). R.1287 / M. 1871 yılı ceyb-i hümâyûn (ceyb ve harc-ı hâssa-i şahane) defterlerinin transkripsiyonu ve değerlendirilmesi. (Yayınlanmamış yüksek lisans tezi), Gaziantep Üniversitesi Sosyal Bilimler Enstitüsü, Gaziantep 2013.

Işıktaş, E. (2020a). Sultan II. Mahmud'un başikbâli Hüsnü Melek Hanım'ın kıymetli malları üzerine bir değerlendirme. Geçmişten Günümüze Tarih Araştırmaları, (ss.91-111) Ed. Mutlu Adak, Ankara: Gazi Kitabevi.

Işıktaş, E. (2020b). 5249 Numaralı gümrük tarife defterine göre Diyarbakır gümrüğüne getirilen emtialar: emtianın cinsi, vergisi ve emtia-fiyat ilişkisi. Yüzüncü Yıl Üniversitesi Sosyal Bilimler Enstitüsü Dergisi, (50), 109-141.

İrepoğlu, G. (2012). Osmanlı saray mücevheri; mücevher üzerinden tarihi okumak. İstanbul: BKG Yayınevi.

Kara, Y. (2010). Osmanlı'da kadın saltanatı, İstanbul: Yeditepe Yayınevi.

Küçükali, M. (2018). II. Mustafa döneminde ceyb-i hümayun hazinesi masraflarl. (Yayınlanmamış Yüksek Lisans Tezi), İstanbul Medeniyet Üniversitesi, Sosyal Bilimler Enstitüsü, , Türk Dili ve Edebiyatı Anabilim Dalı, İstanbul.

Mert, T. (2007), 19. yüzyılda ihsan-1 şahane, Hediye Kitabl, (ss. 112-133), Haz. Emine Gürsoy Naskalı ve Aylin Koç, İstanbul: Kitabevi.

Ortaylı, İ. (2008). Osmanlı sarayında hayat. İstanbul: Yitik Hazine Yayınları.

Özbilge, E. (2011). Bütün yönleriyle Osmanlı. İstanbul: İz Yayınc1lık. 
Öztürk, N. (2007). Osmanlı kroniklerinde hediye kayıtları (1299-1500). Hediye Kitabı, (ss. 4371), Haz. Emine Gürsoy Naskalı ve Aylin Koç, İstanbul: Kitabevi.

Pakalın, M. Z. (1972). Osmanlı tarih deyimleri ve terimleri sözlüğü. III, Ankara: Milli Eğitim Basımevi.

Parlak, S. (2010). Şah Sultan külliyesi. TDV İslâm Ansiklopedisi, 38, (ss.258-260), İstanbul: İSAM Yayınları.

Reindl-Kiel, H. (2007). Osmanlıda hediye (16 ve17. Yüzyıl). Hediye Kitabı, (ss.102-111) Haz. Emine Gürsoy Naskalı ve Aylin Koç, İstanbul: Kitabevi.

Sahillioğlu, H. (1993). Ceyb-i hümâyun. TDV İslâm Ansiklopedisi, 7, (ss.465-467), İstanbul: İSAM Yayınları.

Tekin, Z. (2002). Osmanlı Devleti'nde kürk ticareti. Türkler, (ss. 754-763), X, Ankara: Türk Tarih Kurumu Yayınları.

Terzi, A. (2000). Hazine-i hassa nezareti. Ankara: Türk Tarih Kurumu Yayınları.

Tunç, Muhammet N. (2013). Ceyb-i hümâyûn hazinesi ve topkapı sarayı müzesi arşivi r.1288 (m.1872) tarihli ceyb ve harc-ı hâssa defterlerinin transkripsiyonu ve değerlendirmesi. (Yayınlanmamış yüksek lisans tezi), Gaziantep Üniversitesi Sosyal Bilimler Enstitüsü, Gaziantep.

Ufki Bey, A.-Bobovius, A.(2013). Saray-ı enderun topkapı sarayında yaşam. İstanbul: Kitap Yayınevi.

Uluçay, Ç. (1992). Harem II. Ankara: Türk Tarih Kurumu Basımevi.

Uluçay, M. Ç. (2001). Padişahların kadınları ve kızları. İstanbul: Ötüken Neşriyat.

Yolal, M. (2013). 01490, 01491 ve 1492 numaralı hazine-i hassa (ceyb-i hümâyûn) defterlerinin transkripsiyonu ve değerlendirilmesi (R.1327 -1328/M.1911-1912). (Yayınlanmamış yüksek lisans tezi), Gaziantep Üniversitesi Sosyal Bilimler Enstitüsü, Gaziantep. 


\section{Ekler}

Ek 1. Şah Sultan Hanım'ın hicri 1213 (1798-1799) senesine ait harcamaların ay bazındaki dağılımı (kuruş)

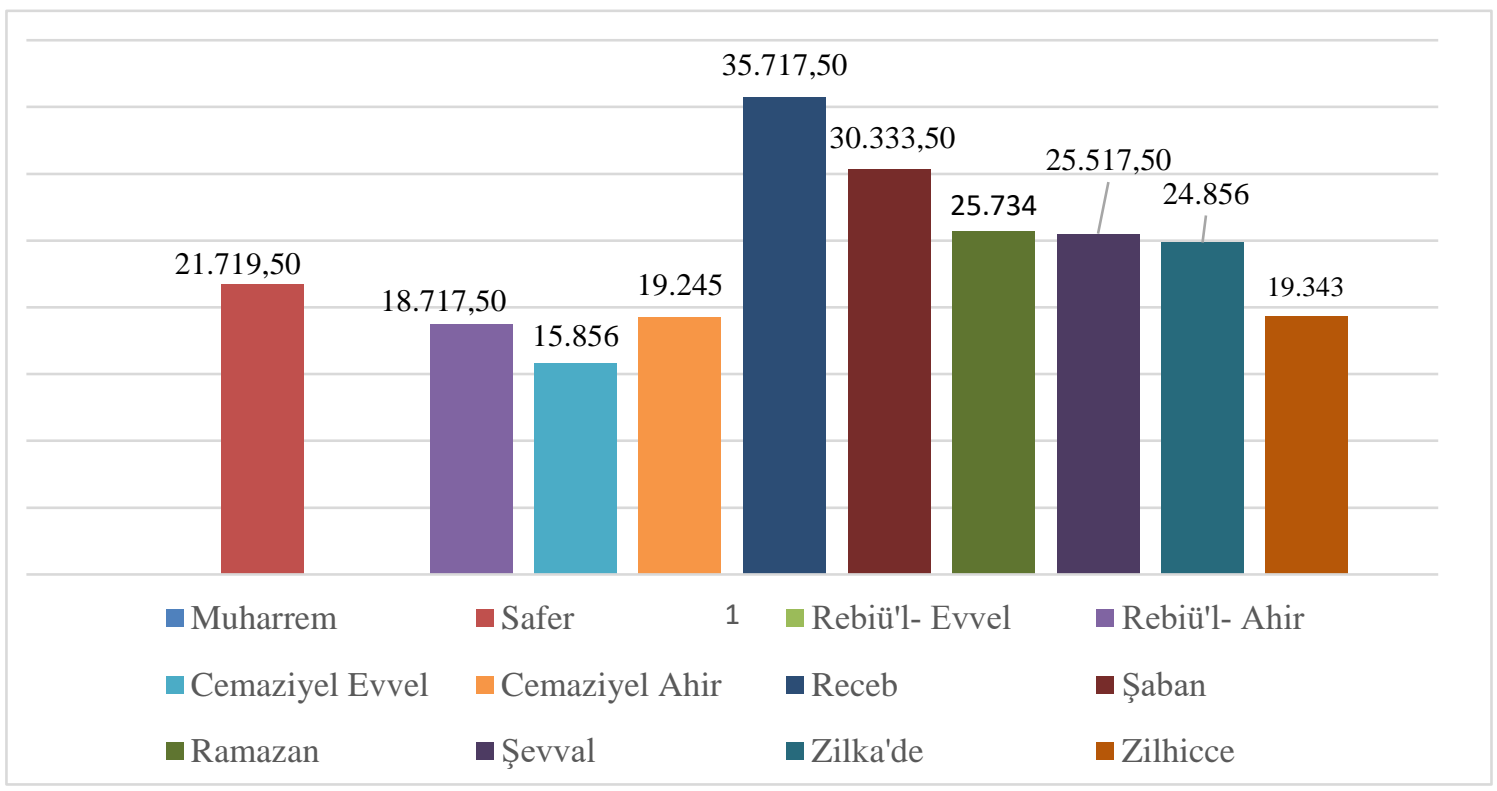

Kaynak: BOA, TS.MA.d., Kutu Numaras1: 3865.

Ek 2. Şah Sultan Hanım'ın Hicri 1214 (1799-1800) senesine ait harcamaların ay bazındaki dağılımı (kuruş)

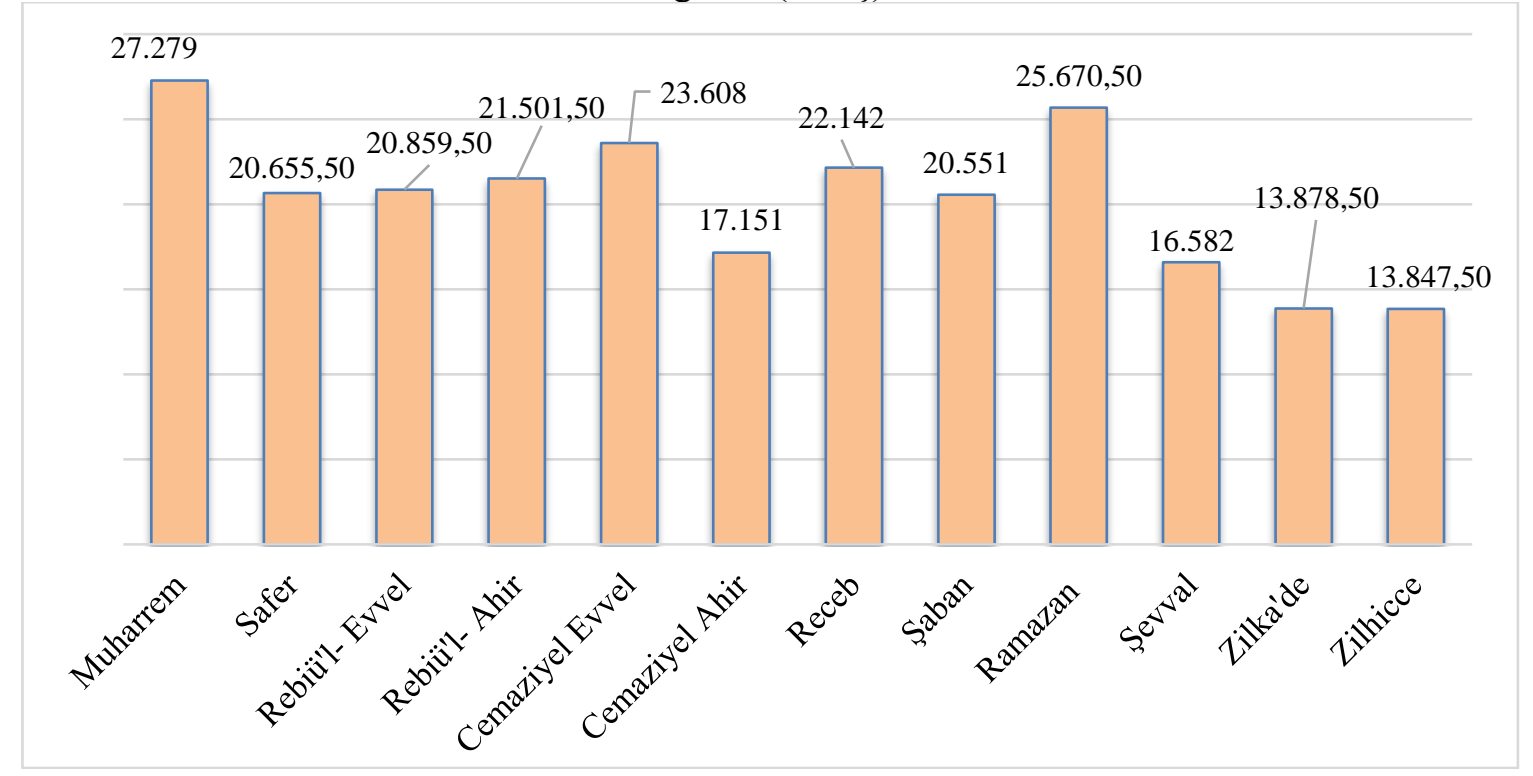

Kaynak: BOA, TS.MA.d., Kutu Numarası: 3865. 
Ek 3. Şah Sultan Hanım'ın Hicri 1215 (1800-1801) senesine ait harcamaların ay bazındaki dağılımı (kuruş)

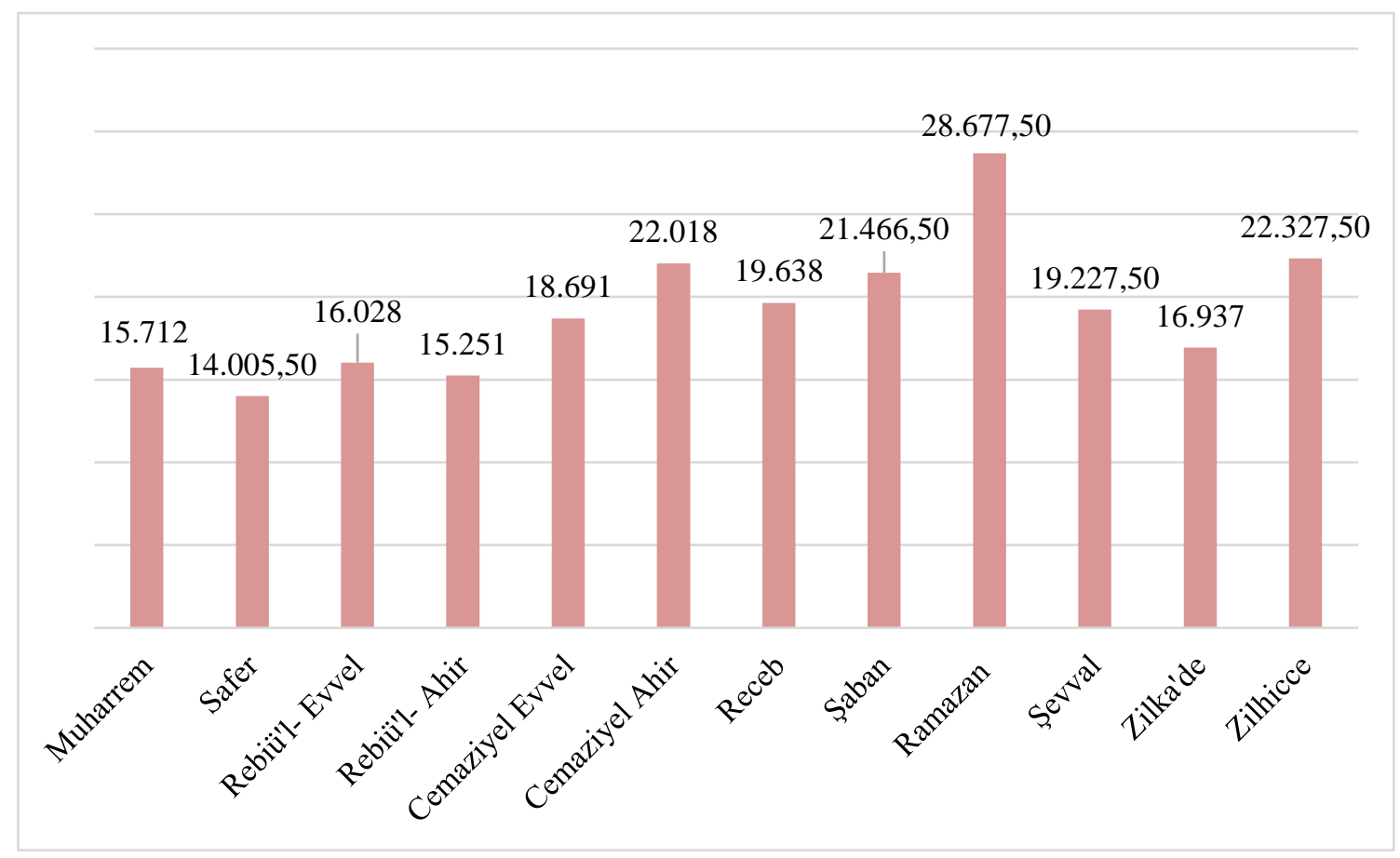

Kaynak: BOA, TS.MA.d., Kutu Numarasi: 3862.

Ek 4. Şah Sultan Hanım'ın Hicri 1216 (1801-1802) senesine ait harcamaların ay bazındaki dağılımı (kuruş)

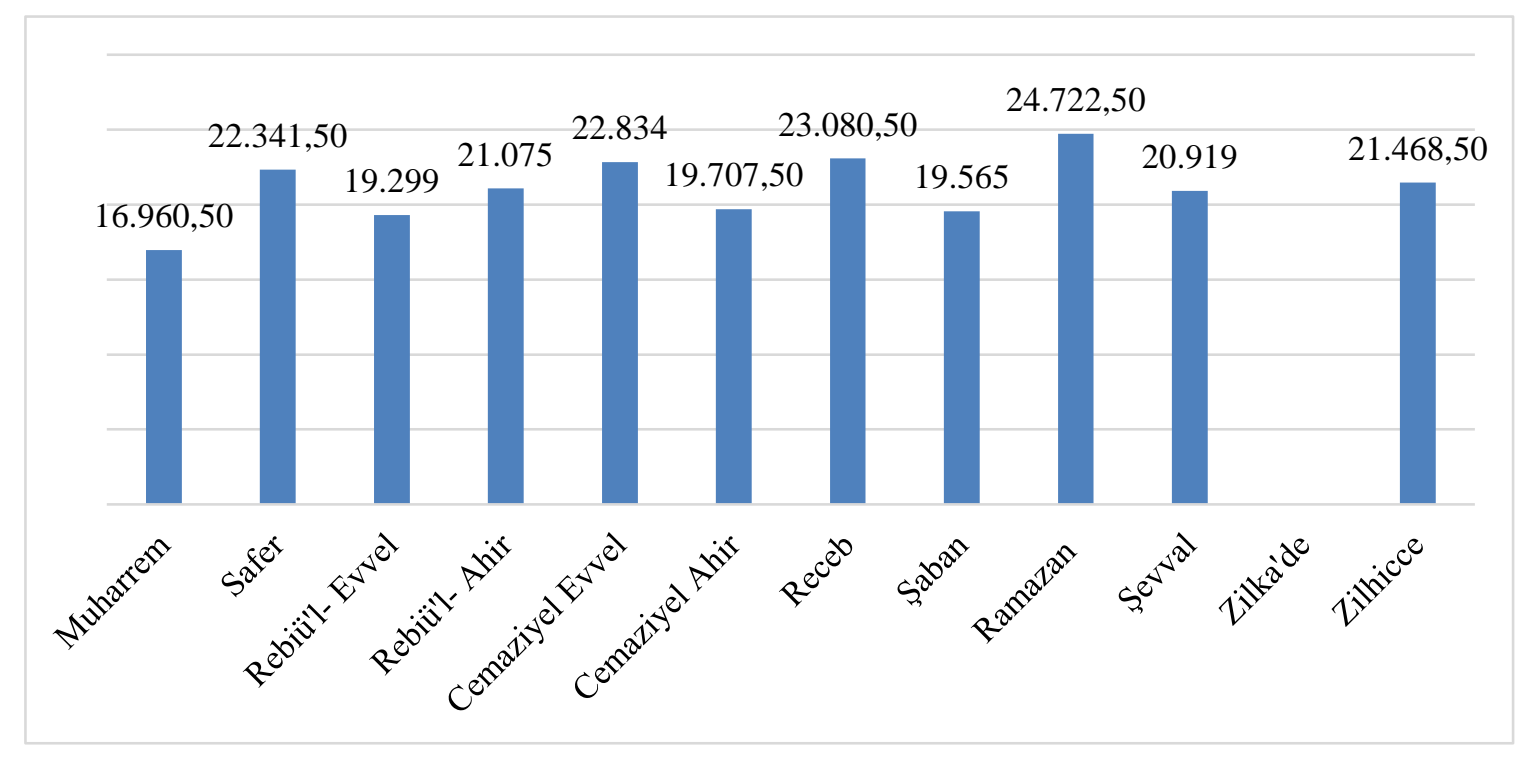

Kaynak: BOA, TS.MA.d., Kutu Numarası: 3863. 
Ek 5. Şah Sultan Hanım'ın Hicri 1217 (1802-1803) senesine ait harcamaların ay bazındaki dağılımı (kuruş)

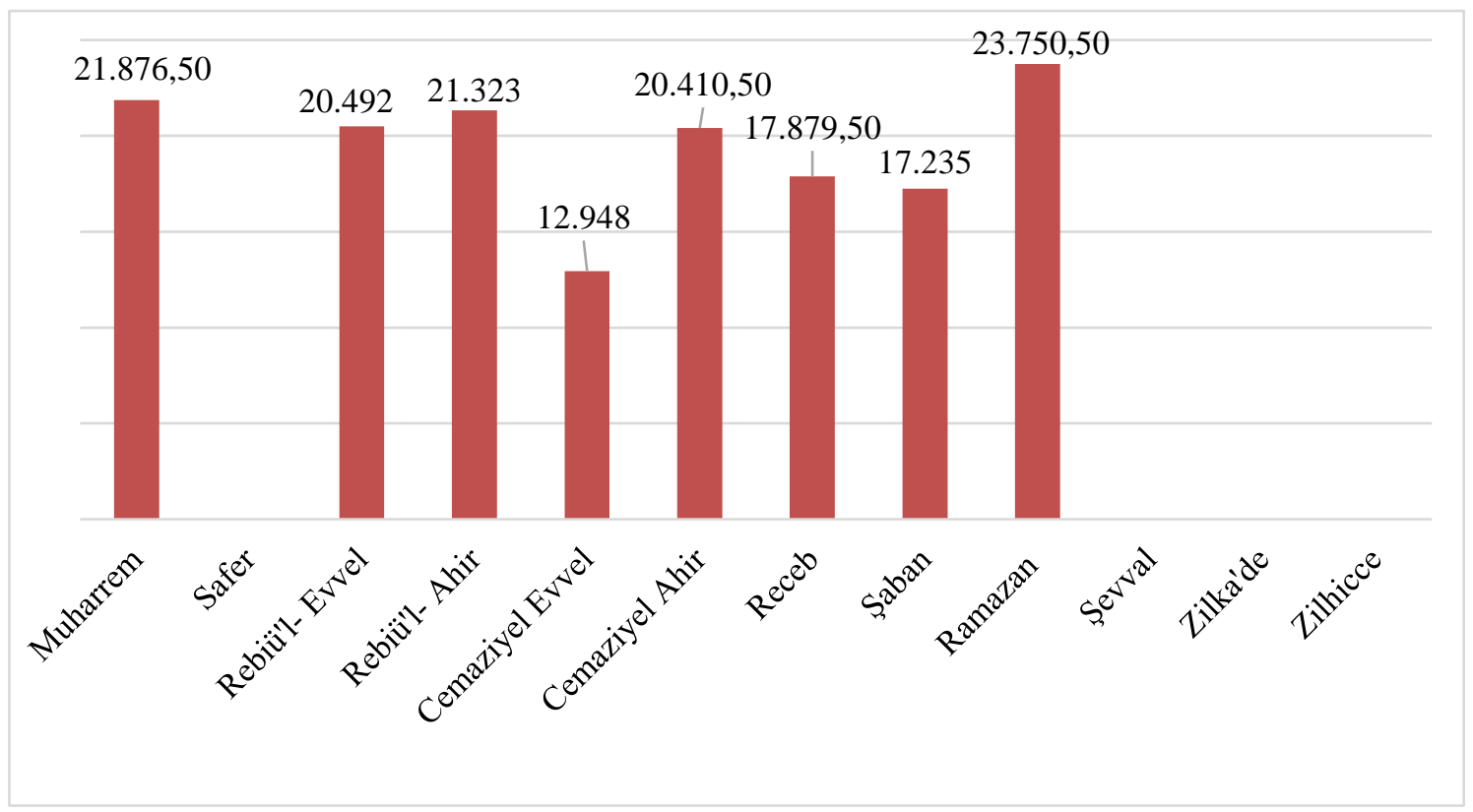

Kaynak: BOA, TS.MA.d., Kutu Numarası: 3866.

Ek 6. Şah Sultan'ın Satın Aldığı Bazı Emtianın Kıymetleri (Örnek)

\begin{tabular}{|c|c|c|c|c|c|}
\hline Eşyanın Cinsi & Ölçü Birimi & $\begin{array}{c}\text { Fiyatı } \\
\text { (Kuruş) }\end{array}$ & Eşyanın Cinsi & $\begin{array}{c}\text { Ölçü } \\
\text { Birimi }\end{array}$ & $\begin{array}{c}\text { Fiyatı } \\
\text { (Kuruş) }\end{array}$ \\
\hline Papazi bürümcek & Tob & 15 & Rızalı şal & Adet & 110 \\
\hline Papazi bürümcek & Tob & 12 & Rızalı şal & Adet & 175 \\
\hline Dallı siyah donluk şal & Adet & 280 & Çuha & Arşın & 11,5 \\
\hline Telli kadife & Zirâ & 18 & Donluk şal & Adet & 150 \\
\hline Rızalı şal & Adet & 220 & Çitari & Adet & 35 \\
\hline Donluk şal & Adet & 190 & Çiçekli keçe & Arşı1n & 5,5 \\
\hline Çar şal & Adet & 150 & Keçe & Tob & 90 \\
\hline Donluk şal & - & 65 & Düz şal & Arşııı & 20 \\
\hline Samur kürk & Adet & 60 & İşleme pullu gezi & Tob & 20 \\
\hline Samur kürk & Adet & 40 & $\begin{array}{l}\text { Beyaz papazi } \\
\text { bürümcek }\end{array}$ & Tob & 28 \\
\hline Samur kürk & Adet & 45 & Donluk şal & Adet & 120 \\
\hline Frengi al keçe bez & - & - & Sungur & Tob & 60 \\
\hline Gügez çuha & - & - & Çuha & Arşııı & 10 \\
\hline Çitari & - & - & Donluk şal & Adet & 400 \\
\hline Rızalı şal & Adet & 150 & Canfes & Arşı1n & 3 \\
\hline Zerli al parça & Adet & 500 & Bursa çitarisi & Adet & 33 \\
\hline Zerli al parça & Adet & 260 & Çiçekli kadife & Zirâ & 17 \\
\hline Zerli al parça & Adet & 210 & $\begin{array}{c}\text { Tulum kakum } \\
\text { kürk }\end{array}$ & Adet & 145 \\
\hline Bursakârî zerli çitari & Adet & 90 & Çar şal & Adet & 135 \\
\hline Düz şal & Adet & 19 & $\begin{array}{c}\text { Turuncu donluk } \\
\text { şal }\end{array}$ & Adet & 200 \\
\hline
\end{tabular}




\begin{tabular}{|c|c|c|c|c|c|}
\hline Rızalı şal & Adet & 160 & Dîbâ & Zirâ & 11 \\
\hline Elmaslı çiçek & Adet & 390 & Tülbent & Tob & 50 \\
\hline Elmaslı çiçek & Adet & 155 & Sarı şal & Adet & 350 \\
\hline Kakum kürk & Adet & 125 & Telli dîbâ & Arşıın & 10 \\
\hline Sade çiçekli şal & Adet & 65 & Kaput & Adet & 40 \\
\hline Kakum kürk & Adet & 115 & Kaputluk çuha & Arşıın & 19 \\
\hline Kakum kürk & Adet & 120 & Elvan çuha & Arşıın & 10,5 \\
\hline Rızalı şal & Adet & 170 & Düz şal & Arşııin & 19 \\
\hline Rızalı şal & Adet & 265 & Trabzon bezi & Tob & 37 \\
\hline Rızalı şal & Adet & 190 & $\begin{array}{l}\text { Siyah zerli âlâ } \\
\text { sava'̂̂ }\end{array}$ & Adet & 260 \\
\hline $\begin{array}{c}\text { Rızalı ve gözlü çıkılı } \\
\text { şal }\end{array}$ & Adet & 300 & Çuha & Arşın & 13 \\
\hline $\begin{array}{c}\text { Rızalı ve gözlü çıkılı } \\
\text { şal }\end{array}$ & Adet & 18 & Çitari & Adet & 35 \\
\hline Çuha & Arşın & 13 & Sava'î & Adet & 250 \\
\hline Şal & Zirâ & 4 & Düz sava'î & Adet & 60 \\
\hline Şal & Adet & 165 & Taraklı telli çitari & Adet & 60 \\
\hline Hind parçası & Adet & 200 & Ala şal & Adet & 375 \\
\hline Tulum kakum kürk & Adet & 120 & Şal & Adet & 275 \\
\hline Donluk şal & Adet & 170 & Lacivert şal & Adet & 220 \\
\hline Beyaz hint çiçekli & Adet & 120 & Çitari & Adet & 40 \\
\hline Sade Hint çiçekli & Adet & 65 & $\begin{array}{l}\text { Alt1 safir } \\
\text { bürümcek }\end{array}$ & - & 21 \\
\hline Çiçekli canfes & Zirâ & 6 & Donluk beyaz şal & Adet & 180 \\
\hline Beyaz işleme donluk & Tob & 60 & $\begin{array}{l}\text { Zerli İstanbul } \\
\text { çiçeklisi }\end{array}$ & Adet & 190 \\
\hline Çitari & Adet & 44 & $\begin{array}{l}\text { Beyaz çıkılı rızalı } \\
\text { şal }\end{array}$ & Adet & 200 \\
\hline Rızalı şal & Adet & 200 & Ufak çiçekli Şal & Adet & 130 \\
\hline Çuha & Arşın & 10,5 & Penbe işleme & Adet & 150 \\
\hline Telli Hint kumaşı & Taka & 200 & Yeşil işleme & Adet & 130 \\
\hline Tulum kakum kürk & Adet & 140 & İngiliz çuha & Arşııin & 13 \\
\hline İşleme şal & Endaze & 60 & Samur kürk & Adet & 430 \\
\hline Telli çitari & Adet & 70 & Atlas & Arşııin & 4 \\
\hline Hatâyî & Arşın & 7 & Çitari & Adet & 40 \\
\hline Dîbâ & Arşın & 11 & Çitari & Adet & 36 \\
\hline Gezi & Tob & 35 & Çitari & Tob & 35 \\
\hline Hint çitari & Adet & 45 & $\begin{array}{c}\text { İngilizkâri basma } \\
\text { çûhâ }\end{array}$ & Zirâ & 9,5 \\
\hline Yakut yüzük & Adet & 350 & Al gezi & Adet & 50 \\
\hline Mücevher iğne & Adet & 140 & $\begin{array}{l}\text { Pirlanta elmasli } \\
\text { iğne }\end{array}$ & Adet & 133 \\
\hline Mücevher kuşak & Adet & 460 & Mücevher kuşak & Adet & 230 \\
\hline Elmas küpe & Adet & 150 & Mücevher kuşak & Adet & 500 \\
\hline Yakut yüzük & Adet & 550 & Mücevher kutusu & Adet & 570 \\
\hline Elmas başlı bilezik & Çift & 253 & Elmas iğne & Adet & 195 \\
\hline Mücevher kutusu & Adet & 800 & Mücevher iğne & Adet & 60 \\
\hline
\end{tabular}




\begin{tabular}{cccccc}
\hline Mücevher avize & Adet & 520 & Elmas kuşak & Adet & 325 \\
Mücevher kutusu & Adet & 710 & Elmas yüzük & Adet & 40 \\
Mücevher kutusu & Adet & 140 & Mücevher avize & Adet & 550 \\
Elmas başlı bilezik & Çift & 220 & Elmas yüzük & Adet & 200 \\
Mücevher kuşak & Çift & 350 & Mücevher kutusu & Adet & 650 \\
Elmas bilezik & Çift & 1370 & Mücevher kutusu & Adet & 520 \\
Elmas Küpe & Adet & 510 & Demir küpe & Adet & 340
\end{tabular}

Kaynak: BOA, TS.MA.d., Kutu Numaralar1: 3862, 3863, 3865, 3866.

ETİK ve BİLIMMSEL İLKELER SORUMLULUK BEYANI

$\mathrm{Bu}$ çalışmanın tüm hazırlanma süreçlerinde etik kurallara ve bilimsel atıf gösterme ilkelerine riayet edildiğini yazar(lar) beyan eder. Aksi bir durumun tespiti halinde Afyon Kocatepe Üniversitesi Sosyal Bilimler Dergisi'nin hiçbir sorumluluğu olmayıp, tüm sorumluluk makale yazarlarına aittir. 